\title{
New Radiocarbon Ages of Colonization Sites in East Polynesia
}

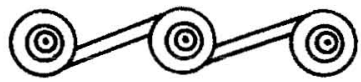

\section{ATHOLL ANDERSON AND YOSIHIKO SINOTO}

NEW RADIOCARBON AGES FOR TWO KEY SITES of East Polynesian prehistoric colonization are presented and discussed in relation to additional results from recent research. Before coming to these it is necessary to specify the methodological stance adopted here concerning the definition of colonization and its visibility in radiocarbon chronologies. Colonization is a concept grasped more easily in the abstract than it is disclosed empirically by archaeological or related data. In the context of East Polynesian prehistory it expresses the general idea of earliest human settlement, but whether that means the first human contact of any kind, the first occupation, or the first permanent settlement is open to question on several counts discussed elsewhere (Anderson 1995; Graves and Addison 1995). Here we can deal only with sites that have been identified as belonging to the colonization era on the grounds that they contain examples of the earliest artifactual types known in East Polynesia and generally disclose a characteristic faunal signature of remains from extinct birds, marine mammals, and turtles (e.g., Leach et al. 1984; Steadman and Rolett 1996).

We accept that colonization need not have been an instantaneous event and that the probability of the earliest actual sites of colonization being represented amongst currently known sites is relatively low in general. Nevertheless, in detailed analysis of early radiocarbon ages, we prefer to emphasize provenance by using indubitably archaeological samples and by taking a site-by-site approach ("chronometric hygiene," e.g., Anderson 1991; Spriggs and Anderson 1993). There is an acknowledged risk of eliminating the presumed few and perhaps poorly provenanced results that may represent the earliest stage of colonization. However, this seems less problematic than the potential difficulties inherent in methods that rely upon inspection of trends in large and indiscriminate assemblages of potentially relevant radiocarbon determinations (e.g., Anderson 1989; Graves and Addison 1995; Hunt and Holsen 1991). These characteristically exhibit a "tail" of data extending earlier than it is possible to date any particular archaeological site. Dates with poor provenance, or inadequate laboratory pre-

Atholl Anderson is the Professor of Prehistory in the Research School of Pacific and Asian Studies, and Director of the Centre for Archaeological Research, at the Australian National University, Canberra, and Yosihiko Sinoto, senior anthropologist, is semi-retired from the B. P. Bishop Museum, Honolulu, Hawai'i. 
treatment, and samples with high inbuilt age or of nonarchaeological origin, such as old soil charcoals from natural fires, may account anonymously for the oldest results. Our conservative preference enjoins the pragmatic consequence that the earliest archaeological sites identified as belonging to the colonization phase might not represent the beginning of it.

\section{CENTRAL EAST POLYNESIAN ARCHAEOLOGICAL CHRONOLOGIES}

The consensus in East Polynesian colonization chronology since the 1960s is that, whatever the actual ages, the settlement of central East Polynesia preceded habitation at the margins, and that the temperate region was colonized last. Only suggestions of Amerindian landfalls in the eastern margins have offered any challenge, and that never satisfactorily realized. How early East Polynesia was colonized is a question thus narrowed to the chronology of the central region and focused upon a handful of archaeological sites which, though by no means the only sites in the region to produce chronological, faunal, and artefactual evidence indicative of early occupation, have stood for 30 years or more as key sites in the ongoing debate. They are: Motu Paeao cemetery (Maupiti) and Vaito'otia-Fa'ahia (Huahine) in the Society Islands, and Hane (Ua Huka) and Ha'atuatua (Nuku Hiva) in the Marquesas Islands.

The early chronological research on these sites began with Suggs (1961) who dated Ha'atuatua to as early as 150 B.C. (in discussing earlier radiocarbon results we give the calendrical ages estimated at the time- see Kirch [1986] for a summary of the early research, Spriggs and Anderson [1993] for recent calibrated ages of older determinations). This seemed to fit the slightly later dates for South Point, Hawai'i, and such early ages led Sinoto and Kellum (1965) to regard their first Gakushuin Laboratory (GaK) results for Hane, Level V, at about A.D. 850, as too recent. A new radiocarbon date series from Gakushuin and an additional series from Washington State University Laboratory (WSU) enabled Sinoto (1970) to propose initial colonization in the period A.D. 300-600.

The Maupiti cemetery was dated to about 1100 B.P. although comparative analysis of material culture suggested that it had probably come into use several hundred years earlier (Emory and Sinoto 1964). The Vaito'otia-Fa'ahia site produced determinations extending to about 1150 B.P., translated approximately as A.D. 800-850 (Sinoto and McCoy 1975). Sinoto (1979, 1983) and colleagues (e.g., Emory 1979) thought these dates too late as well, preferring an age around A.D. 650 on evidence of material culture compared with that at the Hane site. This view arose, additionally, through typological reference to Wairau Bar, where upper layers of the site had been dated originally to about A.D. 1000-1100 (Duff $1977: 354$ ) and the lower "Moa-hunter" burials, especially burials numbered 1-7, were thought possibly older again. It was commonly assumed that some centuries must have elapsed between the colonization of central East Polynesia and New Zealand. Since the Wairau Bar material culture appeared to be a more developed version of ancestral East Polynesian assemblages, the age of that site imposed a terminus ante quem of about A.D. 700-800 on the colonization sites of central East Polynesia.

In an influential review of the evidence and arguments, Kirch (1986) argued that the Gakushuin determinations for Hane, preferred by Sinoto, should be dis- 
carded, on grounds of inconsistency amongst results from this laboratory. Those results fell generally into the second millennium A.D., whereas the remaining Washington State series suggested occupation began about 2000 years ago. Given results of about 2000 B.P. for Hanatekua rockshelter on Hiva Oa, and even earlier for the Anapua rockshelter on Ua Pou (Ottino 1992), initial colonization at about 2000 years ago seemed plausible for the Marquesas. If they had been settled through the Society and Tuamotu Islands, then it followed that initial East Polynesian colonization was older still, by an indeterminate margin.

A later analysis of the Hane chronology (Anderson et al. 1994) concluded that initial occupation had occurred about A.D. 300-600 (see also Rolett 1998). This agreed with the results of a site-by-site approach to the East Polynesian chronology as whole (Spriggs and Anderson 1993) and, with some objections (e.g., Kirch and Ellison 1994), initial colonization of the region in about the middle of the first millennium A.D. became a tacitly accepted conclusion.

Nevertheless, the chronological data for the key sites of central East Polynesia remained quite unsatisfactory, and then intolerably so when Rolett and Conte (1995) demonstrated that Ha'atuatua had been occupied mainly around the fifteenth century and probably no earlier than the tenth century A.D. Renewed chronological research at Wairau Bar (Higham et al. 1999) showed, consistent with much similar research in Moa-hunter sites (e.g., Anderson 1991; Anderson and Smith 1992; Anderson and Wallace 1993; Anderson et al. 1996), that occupation had occurred in the late thirteenth rather than the tenth century A.D., thereby lifting the former apparent restriction on later central East Polynesian colonization.

Our reaction to the changing data for these sites was to re-examine the other three main cases in the historical debate. We began with Motu Paeao. Renewed excavations and chronological research showed that the cemetery was mainly in use in the fifteenth century and probably not earlier than the thirteenth century A.D. (Anderson et al. 1999), a significantly younger age than earlier supposed. Thus we come to the two remaining sites: Vaito'otia-Fa'ahia and Hane.

\section{RADIOCARBON AGES FOR VAITO'OTIA-FA'AHIA AND HANE}

The new radiocarbon ages from Vaito'otia-Fa'ahia and Hane (Tables 1, 2) are upon samples obtained by Sinoto during his excavations at these sites. In each case, samples were chosen to represent the range of areal and stratigraphic variation and the main types of materials; charcoal, charred wood, bone, and marine shell. All samples had been retained in aluminium foil since excavation and sealed in glass jars. Each was weighed and, in the case of artifactual material, drawn and photographed prior to processing. No attempt was made to identify charcoal or wood samples to timber type, and the results are therefore maximum ages in relation to potential inbuilt age.

The radiocarbon determinations were made at Waikato Radiocarbon Laboratory (Wk) and the Australian National University Radiocarbon Laboratory (ANU). They used the following pretreatment methods. Charcoals at Waikato were washed in hot 10 percent $\mathrm{HCl}$, then hot 2 percent $\mathrm{NaOH}$, with the $\mathrm{NaOH}$-insoluble fraction washed in hot 10 percent $\mathrm{HCl}$, filtered, rinsed, and dried. A similar acid-base-acid treatment was used at ANU. The integrity of ara- 
gonite in shell samples was checked by X-ray diffraction in both laboratories. Waikato then etched its shell samples for 100 seconds in $2 \mathrm{M}$ dilute $\mathrm{HCl}$, while ANU cleaned surfaces with a dental drill and washed the samples in an ultrasound bath.

The whale bone sample from Vaito'otia (Wk-8094) was subjected to extensive pretreatment by Dr. Fiona Petchey in the Waikato Radiocarbon Laboratory (unpublished report, $30 \mathrm{March} 2000$ ). This included calculation of $\mathrm{N}$ percent on whole bone ( $1.17 \pm 2$ percent), extractable collagen ( 6 percent), and gelatin yields (1.2 percent $\mathrm{CO}_{2}$ corrected gel yield), plus Fourier Transform Infra Red analysis (some diagenesis indicated). The data showed the sample to be of poor preservation, and its age estimate needs to be regarded cautiously.

\section{Vaito 'otia-Fa'ahia}

Vaito'otia-Fa'ahia is a large site (300-by-200 m), important because of its excellent preservation of wood and fiber and because it has produced a range of artifacts indicative of early East Polynesian settlement, plus some wooden and whale bone clubs similar to Maori patu. It is a wet site on a low-lying coastal plain dotted with brackish ponds. Discovered by dredging for hotel construction, the site has been excavated in two main areas, Vaito'otia, mainly on the south side of one large dredge pond (Sinoto and McCoy 1975), and Fa'ahia around the shores of a smaller dredge pond about $80 \mathrm{~m}$ to the north (Sinoto 1979: Fig. 1; Sinoto and Han 1981: Fig. 1).

The cultural remains are found in coastal sediments and some fluvial materials within and beneath post-occupational beach sand deposits. At Vaito'otia, artifacts occurred in three successive layers labelled I, III, IV and the surface of the underlying natural layer V (Sinoto and McCoy 1975); the cultural layers were later re-numbered as III, IV, V, with Layer VI as natural, the system which will be used here. Layer III seems to have been largely an artificial deposit, possibly a late-period house pavement, in the main excavated area. Beneath it are the early cultural layers IV and V, the latter of which contains the most abundant early cultural material. The layer designations for Fa'ahia were also changed during the project. The main cultural layers, II and III in Sinoto (1979) have become IV and V (Sinoto 1988:114) for consistency with Vaito'otia, and those designations are used here. Sinoto $(1988: 114)$ argues that "both sites have two cultural layers, IV and V. Layer V contains the cultural deposit of major importance and layer IV contains beach sand deposited by wave action with many artifacts haphazardly mixed in from layer V." In other words, the early cultural deposits occurred initially in a single cultural level.

The first radiocarbon determination obtained (Table 1) was $1100 \pm 70$ B.P. (GaK-4629) on an unprovenienced piece of whale bone. This was translated as an age of A.D. 850 (Sinoto and McCoy 1975:183), but if a nominal marine correction of -300 to 400 radiocarbon years is applied, then the age would be about 700-800 B.P. Charcoal and coconut shell samples from Area A at Vaito'otia dated 800-900 B.P., but at Fa'ahia, two charcoal samples produced results of about 1100-1200 B.P. (Table 1, the samples for these are now from Layer V). A date published previously only in summary form (Wallin 1993:68) is I-9423. It was on a wooden post which had a delta ${ }^{13} \mathrm{C}$ of $-30.6 \%$ giving a result of $750 \pm$ 
Table i. Radiocarbon Dates from Vaito'otia-Fa“ahia, Huahine, Society Islands

\begin{tabular}{|c|c|c|c|c|c|c|c|}
\hline LAB NO. & LOCATION & $\begin{array}{l}\text { LEVEL, } \\
\text { DEPTH }\end{array}$ & MATERIAL & $\begin{array}{l}\text { SAMPLE } \\
\text { WEIGHT } \\
(\mathrm{g})\end{array}$ & $\begin{array}{l}\text { CONVENTIONAL } \\
\text { RADIOCARBON } \\
\text { AGE (B.P.) }\end{array}$ & $\begin{array}{l}{ }^{13 / 12} \mathrm{C} \\
\text { RATIO }\end{array}$ & $\begin{array}{c}\text { CALENDRIC } \\
\text { AGE AT } \\
2 \text { SD }\end{array}$ \\
\hline \multicolumn{8}{|l|}{ Vaito'otia } \\
\hline \multicolumn{8}{|l|}{ Previous dates } \\
\hline Gak-4629 & Unprov. & & Whale rib coll. & & $1100 \pm 70$ & & $1215-1441$ \\
\hline Gak-5243 & D15 & Layer IV & Charcoal & & $810 \pm 80$ & & 1027-1379 \\
\hline Gak-5244 & D14 & Layer V & Coconut shell & & $910 \pm 75$ & & $989-1277$ \\
\hline I-9423 & E19 & Layer V & Wood & & $715 \pm 89$ & & $1161-1411$ \\
\hline \multicolumn{8}{|l|}{ New dates } \\
\hline ANU-11235 & E25-12 & Layer IV & Terebra shell & 35.6 & $1040 \pm 60$ & $3.8 \pm 0.3$ & $1282-1460$ \\
\hline ANU-11237 & J5 & Layer V & Charcoal & 6.5 & $920 \pm 110$ & $-19 \pm 2.0$ & $894-1291$ \\
\hline Wk-8093 & E21-29 & Layer V & Pearl shell & 37.7 & $1260 \pm 40$ & $2.4 \pm 0.2$ & 1066-1291 \\
\hline Wk-8094 & $\mathrm{J} 7-2$ & Layer IV & Whale bone coll. & 38 & $1260 \pm 150$ & $-23 \pm 0.2$ & $890-1437$ \\
\hline ANU-11377 & E25-12 & Layer IV & Terebra shell & 46.7 & $1120 \pm 60$ & $3.5 \pm 2.0$ & $1266-1450$ \\
\hline ANU-11375 & E5-2-2 & Layer III & Terebra shell & 80.7 & $2100 \pm 60$ & $0.2 \pm 2.0$ & $143-463$ \\
\hline \multicolumn{8}{|l|}{ Fa'ahia } \\
\hline \multicolumn{8}{|l|}{ Previous Dates } \\
\hline I-10.769 & Sec. 3, N43 & Layer V & Charcoal & & $1120 \pm 80$ & & $692-1145$ \\
\hline $\mathrm{I}-10.770$ & Sec. 3, D19 & Layer V & Charcoal & & $1145 \pm 80$ & & $687-1024$ \\
\hline \multicolumn{8}{|l|}{ New dates } \\
\hline ANU-11239 & $\mathrm{J} 22$ & Layer V & Charred wood & 85.9 & $1230 \pm 50$ & $-19.5 \pm 0.2$ & $669-955$ \\
\hline ANU-11232 & $\mathrm{J} 22$ & Layer IV & Pearl shell & 36.2 & $1250 \pm 60$ & $-0.9 \pm 0.2$ & 1048-1309 \\
\hline ANU-11233 & L23 & Layer V & Pearl shell & 51.3 & $1220 \pm 50$ & $-1.0 \pm 0.2$ & $1106-1316$ \\
\hline ANU-11374 & Q32 & Layer IV & Pearl shell & 97 & $1230 \pm 60$ & $2.2 \pm 2.0$ & $1113-1337$ \\
\hline
\end{tabular}

Note: Calibrations. Stuiver et al. (1998); charcoal Dataset A, marine samples Dataset C (Delta R set at $45 \pm 30$ ). 
89. Normalizing to $-25 \%$, produces a CRA of $715 \pm 89$ (Teledyne Isotopes 15 July 1976 to Sinoto). Ten new samples have been radiocarbon dated, six from Vaito'otia and four from $\mathrm{Fa}$ 'ahia.

\section{New Samples}

All the new Vaito'otia samples (Table 1) are from the main excavation, originally designated Area A, of approximately $288 \mathrm{~m}^{2}$ in extent (Sinoto 1979: Fig 1). Each square was 2-by-2 m, numbered alphabetically north-south and by odd numbers east-west. Two samples are worked Terebra shells from Square E25 in the northwest section of the excavation (ANU-11235, ANU-11377) and another worked Terebra shell sample came from Square E5 at the northeast extremity (ANU11375). Charcoal and whale bone samples (ANU-11237, Wk-8094) came from adjacent Squares J5 and J7 (there was no "6" line of squares, above) in the southeastern section of the excavation. A worked pearl shell sample is from Square E21 near the northern edge of the excavation ( Wk-8093). The most abundant early cultural material came from Layer $\mathrm{V}$, especially wooden artifacts, including a patu. There were also pearl shell lures and baithooks, Terebra shell chisels, pearl shell and turtle bone scrapers, worked whale bone, adzes, and a harpoon foreshaft (Sinoto and McCoy 1975).

Three of the Fa'ahia samples are from Section 2 (Sinoto and Han 1981: Figs. 1 and 3), in which Layer IV contained several piles of Turbo shells near a large, basalt grinding stone. Unfinished and finished adze pieces, both types (A and B) of pearl shell scrapers that occur in the site, Terebra shell chisels, and other artifacts were recovered. In Square L23 was the only pendant from Fa'ahia, a drilled porpoise tooth (Sinoto 1979:4, 17-18). The samples consisted of a large piece of worked timber that had been heavily charred at one end from Square J22, Layer $\mathrm{V}$ (ANU-11239) and, from the same square, Layer IV, a piece of worked pearl shell (ANU-11232). From L23, Layer V came another piece of worked pearl shell (ANU-11233). The remaining sample was worked pearl shell from Layer IV in Square Q32 (ANU-11374). This is in the main Section 5 excavation (Sinoto and Han 1981: Fig. 1), which was excavated in 1981 between Sections 2 and 3.

\section{New Results}

One sample of Terebra shell (ANU-11375) gave a result of second-fifth centuries A.D. (Table 1). This is inconsistent with other samples. Although it is from higher in the cultural deposits at Vaito'otia than any other sample, it is earlier and beyond contact at 2 standard deviations (SD) with any of the other 14 previous or new radiocarbon ages from the site. Outlying results such as this are not uncommon in radiocarbon dating and are seldom easily explained. Our conjecture is that it is an example of an old shell having been used as raw material for tool manufacture. The whale bone result must also be regarded cautiously and it is, in any case, too imprecise to add much value to the chronology.

This leaves the results on shell and charcoal/charred wood. The two samples from Square J22 are from different layers and that might account for the considerable difference in age, except that there are younger dates for lower layers in the same excavation area. In fact, six of the seven charcoal/wood samples in the site 
have radiocarbon ages older, though not by much at Vaito'otia, than any of the shell samples except the anomalous ANU-11375. We suspect that there is an inbuilt-age effect here (Anderson 1991). It is apparent that large timbers were being worked at the site and these probably came from trees of substantial age at the time they were felled, and it is also possible that some pre-occupation, swamp-preserved timber is also represented.

The most reliable radiocarbon ages from the site, therefore, are probably the six shell dates. However, it should be acknowledged that correction for marine reservoir effects at the regional level represented by using the Tahitian offset value is only approximate and could mask significant local variations for which analysis of pre-bomb samples is required. This was not attempted in the current study. Excluding ANU-11375, the new suite of Vaito'otia-Fa'ahia shell dates has a 2 SD span of about A.D. 1050-1450, and perhaps the three Fa'ahia results suggest occupation slightly earlier in that period than the three from Vaito'otia (Fig. 1).

\section{Hane}

Hane is a large, coastal dune site with deep and complex stratigraphy that contained a wide range of chronologically diagnostic artifacts, plus some ceramics. It is, therefore, very important to an understanding of the regional sequence. It was
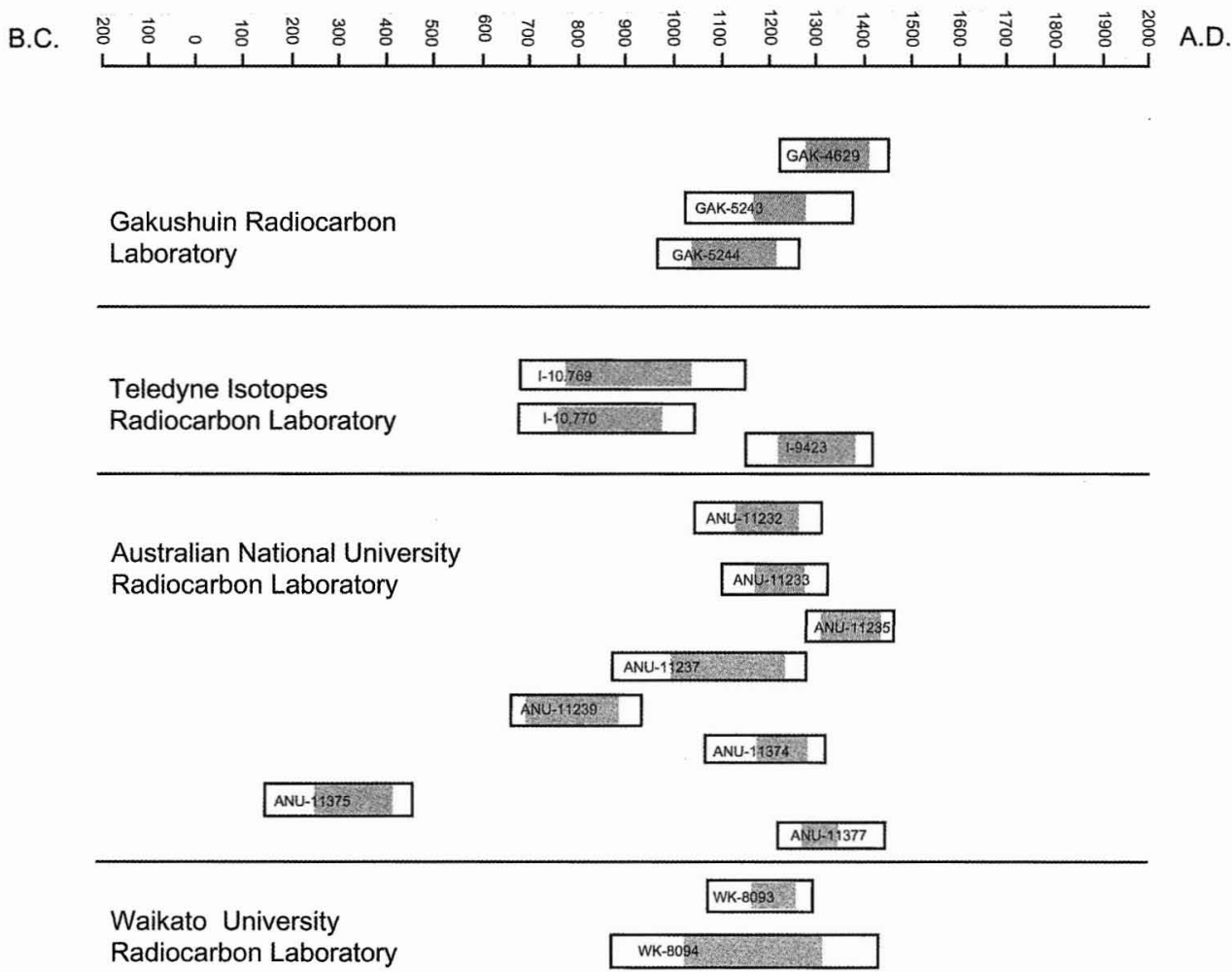

Fig. 1. Calibrated radiocarbon ages (outline bar $=2 \mathrm{SD}$, shaded area $=1 \mathrm{SD}$ ), by laboratory, for samples from Vaito'otia-Fa'ahia, Huahine, Society Islands. 
excavated in three areas, Area A on the lower coastal slope of the dune, Area B on the upper slopes and ridge of the dune, and Area C further inland. Areas A and B are most pertinent to the early chronology (see Anderson et al. 1994: Fig. 1). The site stratigraphy, plans, and contents have yet to be published in detail. The chronology, as noted above, has been discussed by Sinoto and Kellum (1965), Sinoto (1966, 1970, 1979), Kirch (1986), Anderson et al. (1994), and Rolett (1998). Only a few observations about the earlier data need be made here.

First, there are no dates for Area B, Level VII, which contained the sherds. They were recovered from a pit which had probably been dug from Level VI, immediately above it. There were no other cultural materials in Level VII. The lower layers at Area B, regarded by Sinoto as the older of the excavation areas, were dated, therefore, by only one University of Pennsylvania Laboratory determination (P-1123), on charcoal, of $657 \pm 66$ B.P. from Level V/VI (Table 2). Second, many Gakushuin and Washington State determinations are contradictory in age, relative to levels and between charcoal and shell or bone samples. It is this, above all, which created the intractable complexity of the chronology. Third, if the Gakushuin date assemblage is discarded and the Washington State series is preferred, then it is open to alternative conclusions. Kirch (1986) constructed from it an argument in favor of early initial occupation. However, if the youngest of paired determinations was preferred (WSU-512, rather than WSU-491 and WSU-490 rather than WSU-516), and given that the remaining WSU determinations have two-sigma ranges that reach cal A.D. 1000 or younger, then a short chronology was possible at Hane, though no more plausible than its longer alternative.

\section{New Samples}

Ten new samples have been dated, three from Area A and seven from Area B (Table 2). The Area A samples are from adjacent squares at a depth of 416-440 $\mathrm{cm}$ below the site datum. They were in Level IV, which Sinoto and Kellum (1965; Sinoto 1966) equate with Level V or VI in the main mound of Area B. It consisted of light-colored sand with scattered midden, probably derived from a lens immediately below (Level V, which was the lowest cultural deposit). Artifacts, which included worked pearl shell, fishhooks, adzes, and a Tonna shell scraper, were concentrated in Levels IV and V in Squares N-O 108 (Sinoto and Kellum 1965 : 13).

Six of the Area B samples are from the southern part of the main mound excavation in Squares L-M, 90-98. Samples Wk-8594 and Wk-8595 were from under the third or lower level of pavements in the main mound and are therefore Level VI, as are Wk-8590, ANU-11376, and ANU-11385. Wk-8593 was from under the second pavement level and is from Level IV. The remaining sample, ANU-11384, is from Level IV in the center of the main mound. The Area B samples are associated with a wide range of early East Polynesian material culture, but precise associations by square and level cannot yet be provided.

The complexities of the Hane stratigraphy are such that following contemporaneous levels across the site was very difficult. However, the stratigraphy can be divided broadly for the purposes of analysis into two groups; the lower levels ( $\mathrm{V}$, VI, VII in Area B, which, in the center of the main mound, are associated with 
Table 2. Radiocarbon Data from Hane, Ua Huka, Marquesas Islands

\begin{tabular}{|c|c|c|c|c|c|c|c|}
\hline LAB NO. & LOCATION & LEVEL/DEPTH & MATERIAL & $\begin{array}{l}\text { SAMPLE } \\
\text { WEIGHT } \\
\text { (g) }\end{array}$ & $\begin{array}{l}\text { CONVENTIONAL } \\
\text { RADIOCARBON } \\
\text { AGE (B.P.) }\end{array}$ & ${ }^{13 / 12} \mathrm{C}$ RATIO & $\begin{array}{c}\text { CALENDRIC } \\
\text { RANGE A.D. AT } \\
\text { 2SD }\end{array}$ \\
\hline \multicolumn{8}{|c|}{ Previous dates $^{1}$} \\
\hline Gak-529 & Area B, square O86 & $\mathrm{V}$ & charcoal & & $1100 \pm 100$ & & $688-1160$ \\
\hline Gak-530 & Area $A$, square $\mathrm{R} 108$ & VI & charcoal & & $840 \pm 110$ & & $990-1388$ \\
\hline GaK-531 & Area $\mathrm{A}$, square Q108 & II & charcoal & & $715 \pm 100$ & & $1044-1420$ \\
\hline Gak-930 & Area A & $\mathrm{V}$ & charcoal & & $530 \pm 80$ & & $1292-1487$ \\
\hline Gak-931 & Area $\mathrm{A}$, square Q110 & VI & charcoal & & $660 \pm 80$ & & $1220-1427$ \\
\hline Gak-934 & Area B & $\mathrm{V}$ & charcoal & & $380 \pm 150$ & & $1296-1951$ \\
\hline WSU-490 & Area A, square Q110 & VI & charcoal & & $1345 \pm 195$ & & $260-1147$ \\
\hline WSU-491 & Area B, square K96 & $\mathrm{V} / \mathrm{VI} ?$ & charcoal & & $1675 \pm 195$ & & $86 \mathrm{BC}-\mathrm{AD} 761$ \\
\hline WSU-492 & Area B, square N92 & $\mathrm{V}$ ? & charcoal & & $1380 \pm 160$ & & $343-992$ \\
\hline WSU-512 & Area B, square K94 & $\mathrm{V} / \mathrm{VI} ?$ & marine shell & & $1210 \pm 195$ & & $829-1524$ \\
\hline WSU-516 & Area $\mathrm{A}$, square Q110 & VI & marine shell & & $1915 \pm 200$ & & $74-957$ \\
\hline WSU-524 & Area B, square L86 & $\mathrm{V}$ ? & marine shell & & $1750 \pm 140$ & & $412-1000$ \\
\hline WSU-525 & Area B, square L96 & $\mathrm{VI}$ ? & Turtleshell etc. & & $645 \pm 370$ & & $657-1955$ \\
\hline P-1123 & Area B, square P86 & $\mathrm{V} / \mathrm{VI}$ & charcoal & & $657 \pm 66$ & & $1259-1415$ \\
\hline \multicolumn{4}{|l|}{ New dates } & & & & \\
\hline Wk-8590 & Area B, square M90 & $\mathrm{VI} / 220 \mathrm{~cm}$ & charcoal & 8.1 & $640 \pm 130$ & $-25 \pm 0.2$ & $1160-1482$ \\
\hline Wk-8591 & Area A, square $\mathrm{O} 108$ & $\mathrm{IV} / 440 \mathrm{~cm}$ & charcoal & 1.7 & $1030 \pm 150$ & $-25 \pm 0.2$ & $673-1283$ \\
\hline Wk-8592 & Area A, square N108 & $\mathrm{IV} / 416 \mathrm{~cm}$ & charcoal & 2.1 & $690 \pm 60$ & $-26 \pm 0.2$ & $1223-1401$ \\
\hline Wk-8593 & Area B, square L98-10 & IV/below Pav.2 & pearlshell & 29.2 & $1120 \pm 60$ & $1 \pm 0.2$ & $1213-1421$ \\
\hline Wk-8594 & Area B, square M94-40 & VI/below Pav.3 & pearlshell & 37.4 & $1340 \pm 50$ & $2.3 \pm 0.2$ & $1004-1246$ \\
\hline Wk-8595 & Area B, square L96-24 & VI/below Pav.3 & Cassis shell & 44.6 & $1240 \pm 50$ & $1.9 \pm 0.2$ & 1069-1306 \\
\hline Wk-8596 & Area A, square $\mathrm{O} 108$ & $\mathrm{IV} / 440 \mathrm{~cm}$ & Cassis shell & 57.4 & $1230 \pm 50$ & $2.4 \pm 0.2$ & $1079-1310$ \\
\hline ANU-11376 & Area B, square L94-12 & $\mathrm{V} / 160 \mathrm{~cm}$ & pearlshell & 42 & $1210 \pm 60$ & $1.6 \pm 2.0$ & $1126-1347$ \\
\hline ANU-11384 & Area B, square $\mathrm{O} 86$ & $\mathrm{IV} / 100 \mathrm{~cm}$ & charcoal & 10.3 & $290 \pm 60$ & $-26 \pm 0.2$ & $1451-1946$ \\
\hline ANU-11385 & Area B, square M92 & $\mathrm{V} / 190 \mathrm{~cm}$ & charcoal & 10.2 & $970 \pm 60$ & $-24 \pm 0.2$ & $978-1214$ \\
\hline
\end{tabular}

Calibrations-Stuiver et al. (1998); charcoal Dataset A, marine samples Dataset C (Delta R $45 \pm 30$ ). Note 1: excluding modern results for GaK 528, 933, 935, 936. 
the lower pavement, and beneath it; Levels II to VI in Area A), and the upper levels which are Level I in Area A and Levels I-IV in Area B. Whether Level VII should be regarded as separate from Level VI was questioned by Anderson et al. (1994) and it is not regarded now by Sinoto as a discrete layer.

\section{New Results}

In Area A it can be seen that the two Square O108 samples from Level IV overlap at $2 \mathrm{SD}$, and both also overlap the N-108 charcoal sample result, although that is younger than either of the former. These dates are approximately consistent with Gak-530, 531, 930, and 931 from the lower levels of Area A. The new results are less inconsistent with WSU-490 and quite different from WSU-516 from the same area and levels.

In Area B the two results from the group of upper levels (I-IV) do not overlap, although they are the two youngest results obtained from the new samples. The five results from the lower levels are quite consistent with each other and suggest occupation in the period A.D. 1000-1500 (but probably earlier than A.D. 1350). These results are consistent with the University of Pennsylvania result (P-1123) and overlap with Gak-529 and 934, but not with the modern dates obtained on Gak-528, 933, 935, and 936, all of which are inexplicable. The new results are also inconsistent with WSU-491, 492, and 524, but overlap with WSU-525 (by virtue only of its massive standard error) and with WSU-512.

The new results are predominantly upon samples from the lowest levels of Areas A and B. Unless Level VII in Area B was actually an older stratum, then the new results should provide the approximate age of earliest occupation at Hane. There is substantial agreement amongst the old and new results from four laboratories (ANU, Waikato, Pennsylvania, and Gakushuin), against those from Washington State, to the effect that Hane was occupied relatively later than has been thought. It was probably not earlier than about A.D. 1000, according to the lower calibrated ranges of the new results, and if actually around the medians would be dated approximately A.D. 1100-1200 (Fig. 2).

\section{DISCUSSION AND CONCLUSIONS}

There are relatively few sites attributable to the colonization era in any of the central East Polynesian archipelagos and the caution that sample size recommends in attempting to define the colonization chronology is underlined by technical problems of radiocarbon dating in the region. These arise, inter alia, from inbuilt age in old wood and from geological effects in shell (e.g., Anderson et al. 2001; Dye 1994). The common effect of these sources of variation in East Polynesian chronologies is to make measured ages err on the older side. In addition, however, there is a critical need to obtain a much finer scale of variation in offset values to calibration of the marine reservoir effect. This is especially true of central East Polynesia where the single Tahitian offset value is grossly inadequate for calibrating results on samples spread from the Societies to the Marquesas. Until there has been more systematic research on this and other technical issues, all radiocarbon dates from the region must be regarded as provisional. Nevertheless, 


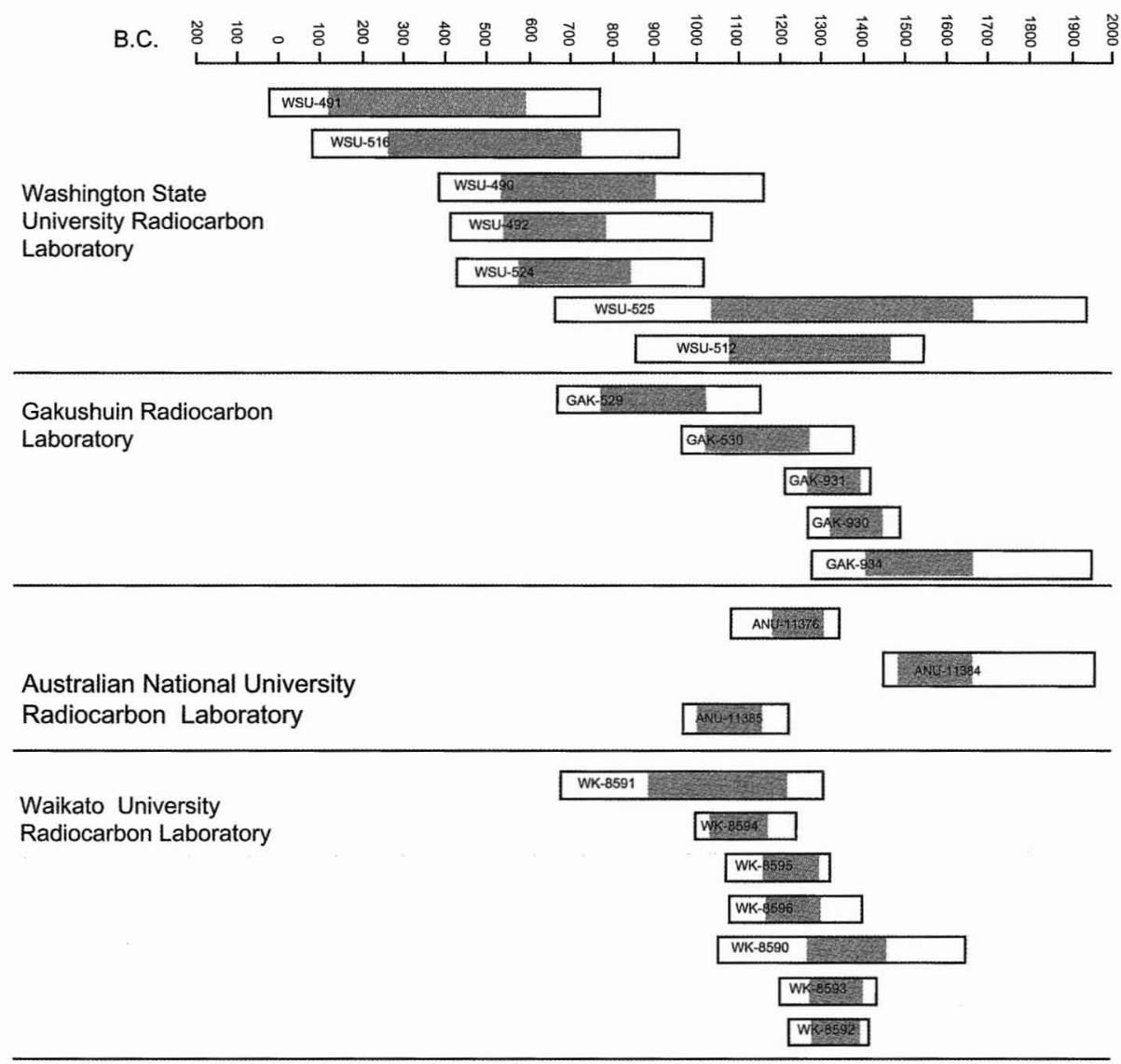

University of Pennsylvania Radiocarbon Laboratory

Fig. 2. Calibrated radiocarbon ages (outline bar $=2 \mathrm{SD}$, shaded area $=1 \mathrm{SD}$ ), by laboratory, for samples from Hane, Ua Huka, Marquesas Islands.

at a regional level, they currently present a reasonably consistent pattern in measuring the age of colonization.

The four key archaeological sites which have been discussed repeatedly in reference to the age of initial colonization in central East Polynesia now appear younger than was earlier thought. Instead of being occupied in the period 100 B.C. to about A.D. 600 as first argued, or in the period A.D. 300-600 as later evaluation concluded, the new radiocarbon results indicate significantly later occupation. This seems to have begun in the period A.D. 900-1200.

A full survey of other data on East Polynesian chronology is beyond the scope of this paper, but it is apparent that the same "younging" trend has been manifested elsewhere. In Hawai'i, the age of South Point is now thought not to exceed about 500 years (Dye 1992), and Bellows Beach, though more difficult to interpret was not occupied earlier than about A.D. 800 and may well be younger 
(Dye 2000; Tuggle and Spriggs n.d.). At Anapua, in the Marquesas, a second set of radiocarbon dates, on shell, turned out 1300 years younger than the charcoal age (Leach et al. 1997), and a site with extinct fauna, at Hanamiai, has a similar age, in the eleventh century A.D. (Rolett 1998). The Tangatatau rockshelter on Mangaia also has extinct fauna in a cultural stratigraphy extending to the eleventh century (Kirch et al. 1995). In Easter Island, the only site containing significant remains of extinct fauna dates to about A.D. 950 (Skjölsvold 1994; Steadman et al. 1994). In addition, newly found or investigated archaeological sites of Polynesian colonization from the subantarctic islands (Anderson and O'Regan 2000) and from Norfolk Island on the remote western margin of East Polynesia (Anderson et al. 2001), are dated to about A.D. 1100-1300.

It is not certain that any of these sites represent the earliest years of human habitation in East Polynesia, and some of the data from marginal East Polynesia, including those above, suggest that sites dating to the late first millennium A.D. ought to occur in central East Polynesia. However, there is no longer an archaeological case, based on a site-by-site approach to chronological data, to support the notion of any colonization earlier than that in the region (Anderson 2001).

Of course, that raises the issue of whether radiocarbon chronologies from archaeological sites are, in fact, more instructive than other kinds of data in measuring the age of colonization. This is another contentious issue under spirited current debate with each of the various kinds of potential evidence of colonization coming under critical scrutiny similar to that directed at the archaeological data. There is debate about the interpretation and dating of botanical and geomorphological change (e.g., Flenley 1996; Kirch and Ellison 1994; Lepofsky et al. 1992; Parkes 1998; contra Anderson 1994, 1995, 2001; McGlone and Wilmshurst 1999; Spriggs and Anderson 1993), and about dating remains of the commensal rat, Rattus exulans (e.g., Holdaway 1999; contra Anderson 2000a; Higham and Petchey 2000). The rapidity and colonization significance of avifaunal extinctions is disputed (e.g., in relation to moas; Holdaway and Jacomb 2000 contra Anderson 2000 ; Schmidt 2000) and the nature and chronological utility of 'archaic' forms of material culture as colonization markers has been challenged (e.g., Kirch 1986; Walter 1996). These issues are not yet amenable to any definitive conclusion (Anderson 2002).

We conclude here that the archaeological data, with all their well-known drawbacks of sampling and survival, are at least the most direct and indisputable remains of human habitation. A conservative approach to the chronology of the key archaeological sites suggests that East Polynesian colonization was later than has been thought - and we will hazard a guess that habitation of any kind may not have begun anywhere in the region before A.D. 900. In principle, if not in practice, that ought to be an easy proposition to overturn.

\section{ACKNOWLEDGMENTS}

Our thanks to Fiona Petchey (Waikato Radiocarbon Laboratory), Lyn Schmidt (Centre for Archaeological Research, ANU), and Paul Wallin and Helene Martinsson-Wallin (Kon-Tiki Museum), as well as an anonymous referee for assistance and useful comment. 


\section{REFERENCES CITED}

ANDERSON, A. J.

1989 Prodigious Birds: Moas and Moahunting in Prehistoric New Zealand. Cambridge: Cambridge University Press.

1991 The chronology of colonization in New Zealand. Antiquity 65:767-795.

1994 Palaeoenvironmental evidence of island colonization: A response. Antiquity 68:845-847.

1995 Current approaches in East Polynesian colonization research. Journal of the Polynesian Society $104: 110-132$.

$2000 a$ Differential reliability of ${ }^{14} \mathrm{C}$ AMS ages of Rattus exulans bone gelatin in South Pacific prehistory. Journal of the Royal Society of New Zealand 30:243-261.

$2000 b$ Defining the period of moa extinction. Archaeology in New Zealand 43:195-200.

2001 The chronology of prehistoric colonization in French Polynesia. In C. M. Stevenson, G. Lee, and F. J. Morin (eds) Pacific 2000: Proceedings of the Fifth International Conference on Easter Island and the Pacific. Easter Island Foundation, Los Osos, pp. 247-252.

2002 Faunal collapse, landscape change and settlement history in Remote Oceania. World Archaeology 33:375-390.

Anderson, A. J., B. Allingham, AND I.W.G. Smith

1996 Shag River Mouth: The Archaeology of an Early Southern Maori Village. Research Papers in Archaeology and Natural History 27. Canberra: ANU.

Anderson, A. J., E. Conte, G. R. Clark, Y. Sinoto, and F. J. Petchey

1999 Renewed excavations at Motu Paeao, Maupiti Island, French Polynesia: Preliminary results. New Zealand Journal of Archaeology $21: 47-66$.

Anderson, A. J., T.G.F. Higham, and R. T. Wallace

2001 The radiocarbon chronology of the Norfolk Island archaeological sites, in, ed. A. J. Anderson and J. P. White. The Prehistoric Archaeology of Norfolk Island, Southwest Pacific. Records of the Australian Museum, Supplement 27, pp. 33-42.

Anderson, A. J., H. M. Leach, I.W.G. Smith, and R.Walter

1994 Reconsideration of the Marquesan sequence in East Polynesian prehistory, with particular reference to Hane (MUH1). Archaeology in Oceania 29:29-52.

Anderson, A. J., AND G. R. O'Regan

2000 To the final shore: Prehistoric colonisation of subpolar Polynesia, in Australian Archaeologist: Collected Papers in Honour of Jim Allen: 440-454, ed. A. J. Anderson and T. Murray. ANU, Canberra: Coombs Academic Press.

Anderson, A. J., AND I.W.G. SMith

1992 The Papatowai site: New evidence and interpretations. Journal of the Polynesian Society 101:129-158.

Anderson, A. J., and R. T. Wallace

1993 The Chronology of Mount Camel Archaic Site, Northland, New Zealand. New Zealand Journal of Archaeology 15:5-16.

Anderson, A. J., AND J. P. White, eds.

2001 The Prehistoric Archaeology of Norfolk Island, Southwest Pacific. Records of the Australian Museum, Supplement 27. Australian Museum, Sydney. In press.

DufF, R.

1977 The Moa-hunter Period of Maori Culture. Wellington: Government Printer.

DYe, T.

1992 The South Point radiocarbon dates thirty years later. New Zealand Journal of Archaeology $14: 89-97$.

1994 Apparent ages of marine shells: implications for dating in Hawai'i. Radiocarbon 36:5157.

2000 Effects of ${ }^{14} \mathrm{C}$ sample selection in archaeology: An example from Hawai'i. Radiocarbon $42: 203-217$.

EMORY, K. P.

1979 The Societies, in The Prehistory of Polynesia: 200-221, ed. J. D. Jennings. Canberra: ANU Press.

EMORY, K. P., AND Y. H. Sinoto

1964 Eastern Polynesian burials at Maupiti. Journal of the Polynesian Society 73:143-160. 
Flenley, J. R.

1996 The palaeoecology of Easter Island, and its ecological disaster, in Easter Island Studies: Contributions to the History of Rapanui in Memory of William T. Mulloy: 27-45, ed. S. R. Fischer. Oxford: Oxbow Books.

Graves, M. W., AND D. J. AdDison

1995 The Polynesian settlement of the Hawaiian archipelago: Integrating models and methods in archaeological interpretation. World Archaeology 26:380-399.

Higham, T.G.F., A. J. Anderson, and C. Jacomb

1999 Dating the first New Zealanders: The chronology of Wairau Bar. Antiquity 73:420-427.

Higham, T.G.F., and F. J. Petchey

2000 On the reliability of archaeological rat bone for radiocarbon dating in New Zealand. Journal of the Royal Society of New Zealand 30:399-409.

Holdaway, R. N.

1999 A spatio-temporal model for the invasion of the New Zealand archipelago by the Pacific rat Rattus exulans. Journal of the Royal Society of New Zealand 29:91-105.

Holdaway, R. N., and C. Jacomb

2000 Rapid extinction of the moas (Aves: Dinornithiformes): Model, test and implications. Science 287: 2250-2254.

Hunt, T. L., AND R. M. Holsen

1991 An early radiocarbon chronology for the Hawaiian islands: A preliminary analysis. Asian Perspectives $30: 147-161$.

KIRCH, P. V.

1986 Rethinking East Polynesian prehistory. Journal of the Polynesian Society 95:9-40.

KirCh, P. V., AND J. Ellison

1994 Palaeoenvironmental evidence for human colonization of Remote Oceanic islands. Antiquity 68:310-321.

Kirch, P. V., D. W. Steadman, V. L. Butler, J. Hather, and M. I. Weisler

1995 Prehistory and human ecology in Eastern Polynesia: Excavations at Tangatatau rockshelter, Mangaia, Cook Islands. Archaeology in Oceania 30:47-65.

Leach, B. F., J. Davidson, M. Horwood, M., and P. Ottino

1997 The fishermen of Anapua rock shelter, Ua Pou, Marquesas Islands. Asian Perspectives $36: 51-66$.

Leach, B. F., M. Intoh, and I.W.G. Smith

1984 Fishing, turtle hunting and mammal exploitation at Fa'ahia, Huahine, French Polynesia. Journal de la Société des Océanistes 79:183-197.

Lepofsky, D., H. C. Harries, and M. Kellum

1992 Early coconuts on Mo'orea Island, French Polynesia. Journal of the Polynesian Society 101:299-308.

MCGlone, M. S., AND J. M. Wilmshurst

1999 Dating initial Maori environmental impact in New Zealand. Quaternary International $59: 5-16$.

Ottino, P.

1992 Anapua: Abri-sous-roche de pêcheurs. Etude de hameçons (première partie). Journal de la Société des Océanistes $94: 57-79$.

Parkes, A.

1998 Environmental change and the impact of Polynesian colonization: Sedimentary records from central Polynesia, in Historical Ecology in the Pacific Islands: Prehistoric Environmental and Landscape Change: 166-199, ed. P. V. Kirch and T. L. Hunt. New Haven: Yale University Press.

Rolett, B. V.

1998 Hanamiai: Prehistoric Colonization and Cultural Change in the Marquesas Islands (East Polynesia). Yale University Publications in Anthropology 81, New Haven.

Rolett, B. V., And E. Conte

1995 Renewed investigation of the Ha'atuatua Dune (Nuku Hiva, Marquesas Islands): A key site in Polynesian prehistory. Journal of the Polynesian Society 104 : 195-228. 
SсHмidt, M.

2000 Radiocarbon dating the end of moa-hunting in New Zealand prehistory. Archaeology in New Zealand 43:314-329.

Sinoto, Y. H.

1966 A tentative prehistoric cultural sequence in the northern Marquesas Islands, French Polynesia. Journal of the Polynesian Society 75:287-303.

1970 An archaeologically based assessment of the Marquesas Islands as a dispersal center in East Polynesia. Pacific Anthropological Records 11:105-132.

1979 Excavations in Huahine, French Polynesia. Pacific Studies 3:1-40.

1983 An analysis of Polynesian migrations based on the archaeological assessments. Journal de la Société des Océanistes 76:57-67.

1988 A waterlogged site on Huahine Island, French Polynesia, in Wet Site Archaeology: 113129, ed. B. A. Purdy. Caldwell, NJ: Telford Press.

SinOTO, Y. H., AND T. HAN

1981 Report on the Fa'ahia site excavations, Zone A, Section 5, Fare Huahine, Society Islands, French Polynesia. Unpublished report, B. P. Bishop Museum, Honolulu.

Sinoto, Y. H., AND M. Kellum

1965 Preliminary report on excavations in the Marquesas Islands, French Polynesia. Unpublished report, B. P. Bishop Museum, Honolulu.

Sinoto, Y. H., AND P. McCoY

1975 Report on the preliminary excavation of an early habitation site on Huahine, Society Islands. Journal de la Société des Océanistes 31:143-186.

Skjörsvold, A.

1994 Archaeological investigations at Anakena, Easter Island. The Kon-Tiki Museum, Occasional Papers 3:5-122.

Spriggs, M., and A. J. ANDERson

1993 Late colonization of East Polynesia. Antiquity 67: 200-217.

Steadman, D. W., and B. Rolett

1996 A chronostratigraphic analysis of landbird extinction on Tahuata, Marquesas Islands. Journal of Archaeological Science 23:81-94.

Steadman, D., Vargas, P., and C. Cristino

1994 Stratigraphy, chronology and cultural context of an early faunal assemblage from Easter Island. Asian Perspectives 33:79-96.

SUGGS, R.

1961 The Archaeology of Nuku Hiva, Marquesas Islands, French Polynesia. Anthropological Papers of the American Museum of Natural History 49, New York.

Tuggle, H. D., and M.T.J. Spriggs

2000 The age of the Bellows dune site $\mathrm{O} 18, \mathrm{O}^{\prime} \mathrm{ahu}$, Hawai' $\mathrm{i}$, and the antiquity of Hawaiian colonization. Asian Perspectives 39:165-188.

WaLLIN, P.

1993 Ceremonial Stone Structures: The Archaeology and Ethnohistory of the Marae Complex in the Society Islands, French Polynesia. Aun 18, Societas Archaeologica Upsaliensis, Uppsala.

WALTER, R.

1996 What is the East Polynesian 'Archaic'? A view from the Cook Islands, in Oceanic Culture History: Essays in Honour of Roger Green: 513-529, ed. J. Davidson, G. Irwin, F. Leach, A. Pawley and D. Brown. New Zealand Journal of Archaeology, Special Publication.

\begin{abstract}
The archaeological chronology of initial human colonization in East Polynesia has relied substantially upon radiocarbon dating results from a small number of sites in the central region, notably Motu Paeao cemetery (Maupiti) and Vaito'otia-Fa'ahia (Huahine) in the Society Islands, and Hane (Ua Huka) and Ha'atuatua (Nuku Hiva) in the Marquesas Islands. Recent field research and new radiocarbon dates showed

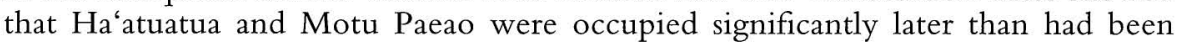


suggested by earlier results. We now report the results of new radiocarbon dating on the remaining two sites. Leaving aside questionable results on bone and wood samples, six shell samples from Vaito'otia-Fa'ahia indicate occupation in the period A.D. 1050-1450. Five shell and five charcoal samples from Hane indicate that occupation did not begin earlier than about A.D. 1000. Taken together with other recent research on the chronology of initial colonization in East Polynesia we suggest that habitation did not begin until A.D. 900 or later. KeYwords: East Polynesia, radiocarbon dates. 